\title{
Development of science practicum performance assessment in junior high school
}

\author{
Ni Luh Rin Riantini ${ }^{\mathrm{a}^{*}}$, I Wayan Suastra ${ }^{\mathrm{a}}$, and Putu Budi Adnyana ${ }^{\mathrm{a}}$ \\ ${ }^{1}$ Science Education, Post-Graduate Program, Ganesha University of Education, Singaraja, Indonesia \\ rinriantini93@gmail.com
}

\begin{abstract}
The purpose of this research was produce a performance science practicum assessment instruments based science process skill which is valid, reliable, practical, and effective for measuring the skill of science process in junior high school. The type of this research is development research designed with the assessment development model from Doran et al., 1998. The average result of the instrument validation test is 3.50 and can be categorized very valid and can be applied in the learning after going through several revisions. Reliability test results show that reliable instrument with reliability coefficient of 0.78 . The average result of the instrument practicality test is 3.38 and it is practically categorized and can be applied in the learning after going through several revisions. From the average student score can be stated all students get the value above the minimal mastery criteria, with students the average score is 83.98 and from the $t$-test results obtained $t$ count 30.376 . Based on these findings, it can be concluded that the instrument assessment of science practicum performance based on science process skills can be used to measure students' science process skills, easy to use in learning, and effectively used in science learning activities.
\end{abstract}

Keywords: assessment, performance, science process skills

\section{Introduction}

The curriculum in force in Indonesia for the last three years is the Curriculum 2013. The learning process in Curriculum 2013 is based on a scientific approach. The scientific approach directs students to the learning process in accordance with the scientific method. Changes in the learning process applied to the Curriculum 2013 led to changes in learning tools including the assessment process. Assessment is done on the competence of attitudes, skills, and knowledge. Assessment is the process of gathering qualitative and quantitative information about the achievements and qualities of a science program [3]. According to [4], assessment is the process of gathering information about learners, regarding what students know and what students do. In the information gathering teachers can observe learners, test the skills, knowledge, and products produced by learners. Assessment activities are not limited to the characteristics of learners only, but also include the characteristics of teaching methods, curriculum, facilities and school administration. Assessment instruments may be formal or informal methods or procedures, to generate information about learners: written tests, oral tests, observation sheets, interview guides, homework assignments, etc. [12]. 
The assessment emphasized in the implementation of the 2013 curriculum is authentic assessment. An assessment is authenticated when the assessment involves learners on useful, important, and meaningful tasks [4]. Authentic assessment will materialize when student learning activities involve an activity that demonstrates high thinking skills as well as coordination of broad knowledge as per contextual learning objectives. Assessment becomes authentic when the learning measured by the assessment has value beyond the classroom and is meaningful to learners. Authentic assessment mandates the skills and abilities needed to perform the actual task. In this connection authentic assessment leads to each goal such as: (1) Demanding learners develop a response rather than simply having a pre-determined option; (2) Raising high-level thinking in addition to basic skills; (3) Directly evaluate a holistic project (task); (4) Integrating with teaching; (5) Using examples of students' work (portfolio); (6) Derived from clear criteria for learners; (7) Allows the emergence of many opinions; (8) Closely connect with classroom learning; (9) Teaches learners to evaluate their own work. (10) is comprehensive and holistic [12]. The judgment used to assess the outcome of the learning process is authentic assessment. Authentic assessment has relevance to the scientific approach in learning according to the demands of the Curriculum 2013 which is able to describe the improvement of learning outcomes of learners. Authentic assessment aims to measure skills in various contexts that reflect realworld situations [6]. One type of authentic assessment that can be used to measure skill competency is performance assessment. In school learning, one of the many subjects using performance assessment in the learning process is science.

Science is the knowledge of the natural surroundings, in this case relates to how to find out about nature systematically, so that science in the school called the Natural Science is not only the mastery of a collection of knowledge in the form of facts, concepts, or principles only, But also a process of discovery [2]. Therefore, science learning in schools should be applied with a scientific approach and students are expected to have skills tailored to the learning process of science. Performance assessment is an assessment of the performance or performance or performance of learners from assignments given teachers where learners perform or display or do something to show achievement in learning [7]. Performance assessment requires students to complete their performance tasks using their knowledge and skills embodied in the form of actions, actions or performance. The Performance Test asks students to embody actual tasks that represent the overall performance to be assessed, such as preparing tools, using tools or assembling tools, writing data, analyzing data, summarizing, reporting and so on. In particular, performance appraisals explain students' abilities, conceptual understanding, ability to apply knowledge and skills, perform performance and ability to perform a process. Science as a product involves a collection of knowledge consisting of facts, concepts, and principles of science. Science as a process includes skills and attitudes possessed by scientists. Aspects of science process skills include eight aspects: observing, interpreting, using tools and materials, predicting, applying concepts, planning activities, communicating, and asking questions [8]. Process skills are skills involving cognitive or intellectual, manual and social skills. Cognitive skills are involved because by doing the process skills the students use their minds [11].

Many teachers who have not implemented a good performance assessment in the learning process can be seen from the results of several studies. In the performance appraisal is also shown in the research conducted by [1], This research researcher about execution of science practicum of class VIII at Junior High School in Lubuk Begalung, Padang City. The results of this study indicate at the stage of practicum planning, where one of the observed aspects of formulating the form and type of explanation clearly and completely get less criteria with a value of $59 \%$. In addition, research conducted by [9], regarding teacher difficulties in the implementation of the assessment in the 2013 
curriculum in Yogyakarta City, one of which is the assessment of skills. The study shows that teachers do not understand the concept of skills assessment, it is difficult to make a skill assessment rubric, and it is difficult for teachers to determine indicators to assess student skills. This is due to the lack of insight and preparation of teachers in assessing the process of practicum. Teachers need to be given an intensive training related to the designing and implementation of authentic assessment both by schools and other institutions [10]. Therefore, research is conducted to produce a valid, reliable, practical, and effective performance assessment instrument.

\section{Method}

\subsection{Research design}

The research development design used in this research is the assessment development model designed by [3]. The steps of assessment development model that state the purpose, select appropriate task format, write or modify the task, clarify administrative procedures, develop the scoring rubric, trial the task, analyze result, revise task. The product trial is done with one shoot case study, Validation test obtained from the average assessment results of two experts, use reliability test inter rater agreement, The practicality test obtained from the average assessment of three science teachers on the instrument, and the effectiveness test using one sample $t$ test.

\subsection{Participants}

Research subjects in this study are two experts, two appraisal teachers, three junior high school teachers, 34 students of grade VIIA SMPN 2 Kuta. Two experts aimed to test the validity of the product, two teachers as assessors aimed at testing product reliability, three junior high school teachers aimed at product practicality test, and students aimed at product effectiveness test. The object of this research includes the assessment instrument of science practicum performance based on science process skills.

\subsection{Instrumentation}

To test validity, each expert is given a validation sheet, which on the validation sheet contains several aspects including: presentation method, and physical form of the instrument. In the validation sheet, the validator's opinion is categorized into four scoring scales, excellent (score 4), good (score 3), not good (score 2), and very bad (score 1). The reliability of performance assessment science practicum based on science process skill can be known from the results of the assessment conducted by two assessors. The results of the assessors will be calculated the number of similarity scores so that it can be known level of reliability. The response questionnaire is a data collection instrument in the form of a number of statements filled by the teacher. The list of statements used in the instrument test phase aims to collect teacher opinion data related to the practicality of the instrument. Questionnaires used in this study using four scales. The results of this questionnaire will be used to test the practicality of the instrument. Scientific performance appraisal sheets are used to measure students' science process skills in practicum work. The performance assessment sheet contains indicators of the science process skills with a scale of 1-4. The practice performance appraisal rubric contains an explanation of the criteria for each score. Student performance appraisal instrument consists of two types of assessment, namely: assessment of student activities and student practice report reports. Rubrics with a scale of 4 
to 5 are effective for defining every aspect that will be used to assess student performance and direction from teachers enabling to improve student discipline as well as maximizing student knowledge development [5]. With the use of analytic rubrics the teacher can be more effective in assessing each student's performance and the results of the assessment more objectively.

\section{Result and discussion}

The results and discussion of the validation test results, reliability, practicality, and effectiveness of the performance assessment tools science-based science process skills are as follows.

\subsection{Validity of performance assessment instrument}

The data of validation result of performance appraisal apparatus of science as follows. Instrument tested validity consist of three instruments that is, first observation sheet of student activity with result of validation 3.47 and get valid predicate, both sheets of report of practice report with result of validation 3.55 and get predicate very valid, third worksheet of student with validation result 3.47 and get a valid predicate. From the result of validity test of each instrument, it can be obtained the average of validation result of the assessment of science practicum performance based on science skill in 3.50 with very valid predicate and can be used to measure students' science process skill so that it can be applied in learning with do some previous revision.

\subsection{Reliability of performance assessment instrument}

In this research, reliability test is done using 34 students from class VIIA. From result of analysis of reliability test obtained result of reliability instrument observation activity of student equal to 0.737 and can be said that instrument have reliable. The result of reliability analysis of appraisal report instrument is 0.82 and it can be said that the instrument has been reliable. The average reliability test results obtained by 0.78 indicating that the developed instrument has been reliable because it has met the minimum reliability of 0.7 . In other words, developed instruments are consistent and are viewed the same when used by more than one teacher or assessor.

\subsection{Practicality of performance assessment instrument}

From the results of practical tests conducted by the three practitioners obtained the average of practicality test results for student activity observation sheets and sheets of practice report report of 3.47 with a practical predicate. Practical test results for student worksheets obtained an average value of 3.28 with a practical predicate. It can be concluded for all the assessment instruments of science science-based science-based practice performance achievement of 3.38 practicality test results with practical predicate. It can thus be concluded that the science-based science performance assessment appraisal instrument is easy to use without finding any significant difficulties in its use. 


\subsection{Effectiveness of performance assessment instrument}

Table 1. One sample t test result

\begin{tabular}{|c|c|c|c|c|c|c|c|c|}
\hline & \multicolumn{5}{|c|}{ Paired Differences } & \multirow{3}{*}{$\mathbf{T}$} & \multirow{3}{*}{ df } & \multirow{3}{*}{$\begin{array}{l}\text { Sig. } \\
(2- \\
\text { tailed) }\end{array}$} \\
\hline & \multirow[t]{2}{*}{ Mean } & \multirow[t]{2}{*}{$\begin{array}{l}\text { Std. } \\
\text { Dev. }\end{array}$} & \multirow[t]{2}{*}{$\begin{array}{l}\text { Std. } \\
\text { Error } \\
\text { Mean }\end{array}$} & \multicolumn{2}{|c|}{$\begin{array}{c}95 \% \\
\text { Confidence } \\
\text { Interval of the } \\
\text { Difference } \\
\end{array}$} & & & \\
\hline & & & & Lower & Upper & & & \\
\hline$(1)$ & $(2)$ & (3) & $(4)$ & $(5)$ & $(6)$ & $(7)$ & $(8)$ & $(9)$ \\
\hline $\begin{array}{l}\text { Performance } \\
\text { score of } \\
\text { practicum of } \\
\text { students - } \\
\text { value of } \\
\text { minimal } \\
\text { mastery } \\
\text { criteria }\end{array}$ & 83.98 & 1.72 & 0.295 & 8.37 & 9.58 & 30.376 & 33 & 0.00 \\
\hline
\end{tabular}

At the first meeting conducted practicum of water pollution. In the water pollution practice the students have not fully understood the student worksheets that have been distributed to each group so that the teacher should provide much guidance to the students. The second meeting is the practice of soil pollution and the third meeting of air pollution practice runs more smoothly than before because students have clearly understood what to do. The value used in the effectiveness test comes from the value of practicum and practicum reports. From the results of effectiveness test at each practice can be obtained results that all students get the value above the minimum mastery criteria with the highest value of 89.55 and the lowest score of 76.25. Judging from the result of one sample t test obtained $t$ count equal to 30.376 and $t$ table equal to 2.042 . Thus, $t$ count $>t$ table $\mathrm{H} 0$ rejected and $\mathrm{Ha}$ accepted, and can be expressed student value bigger or equal with minimum mastery criteria. It can be concluded that the assessment instrument of science practicum performance based on skills in the science process is effective in measuring students 'science process skills and can improve students' science process skills.

\section{Conclusion}

Based on the exposure of the results and discussion of the research, then obtained the following conclusions. (1) Scientific performance appraisal of science practicum based on science process is very valid and can be used in science learning process because instrument can be used to measure students' science process skill. (2) The assessment instrument of science practicum performance based on the skills of the science process can be said reliably with a reliability coefficient of 0.78 , so that the statement on the assessment is consistent. (3) Scientific performance appraisal of practical science-based practical and easy-to-use science-based practice assessment instruments. The instrument has been completed with an appraisal rubric so that it can objectively assess. (4) Scientific performance appraisal tools for science-based science process sciences are effective in measuring students 'science process skills and can improve students' science process skills that are seen from the student's grades in each practicum already exceeding the minimum completion criteria and from one sample $t$ test result where $t$ count $>t$ table. 


\section{Reference}

1. W. N. Atnur, Lufri, S. Ramadhan, Analisis Pelaksanaan Praktikum IPA Biologi Kelas VIII Semester I di SMP Negeri Se-Kecamatan Lubuk Begalung Tahun Pelajaran 2014/2015 (2014).

2. Depdiknas. Laporan IPA (2004).

3. R. Doran, F. Chan, P. Tamir, Science Educator's Guide to Assessment (1998).

4. D. Hart, Authentic Assesment: A Handbook for Educators (1994).

5. Johnson, C. Carla, D. Zang, J. B. Kahle, Research in Middle Level Education 35 (2012).

6. D. A. Lindayani, Penerapan Penilaian Autentik Dalam Kurikulum 2013 (2014).

7. A.A.I.N Marhaeni, L.P. Artini, Jurnal Pendidikan Indonesia 4 (2015).

8. I. W. Suastra, Pembelajaran Sains Terkini Mendekatkan Siswa dengan Lingkungan Alamiah dan Sosial Budaya (2013).

9. H. Retnawati, Analisis Kuantitatif Instrumen Penelitian (Panduan Peneliti, Mahasiswa, dan Psikometrian, 2016).

10. I.W. Suastra, N. P. Ristiati, IRJEIS 3 (2017).

11. N.Y. Rustaman, Strategi Belajar Mengajar Biologi (2003).

12. S. Widodo, E. Irmayanti, Sulistyono. Asesmen Autentik (2011). 